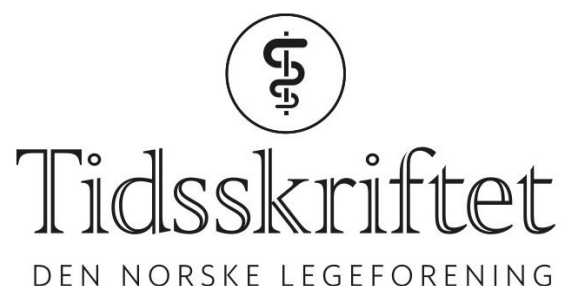

\title{
Lege ved reisens slutt
}

INTERVJU

CHARLOTTE LUNDE

E-post: charlottelunde@me.com

Hun har valgt å være lege for dem i livets siste fase. Det er det mange som har satt - og setter - pris på.

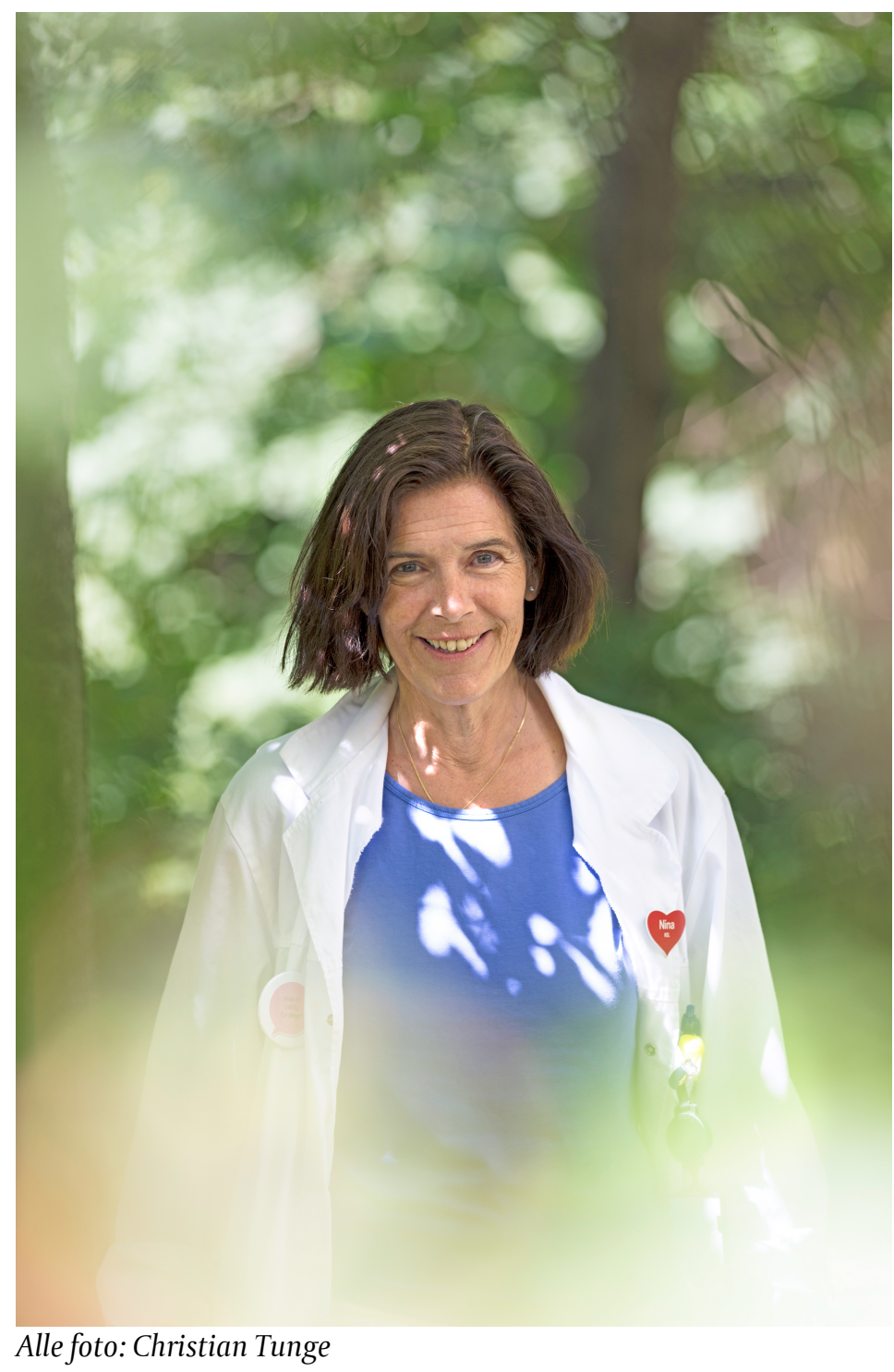

«Fri som fuglen. Takk Nina», står en hilsen skrevet på et fotografi av Erik Bye i et åpent fly. 
Noe av det siste den kreftsyke NRK-mannen ønsket seg før han døde var nettopp en flytur i åpen cockpit. Et ønske Nina Borge var opptatt av å legge til rette for. Rollen som lege ved palliativt team på Diakonhjemmet Sykehus har gitt både utfordringer og gleder. På spørsmål om det har vært krevende, svarer hun tvert:

- Så givende! Det er krevende, men givende i samme åndedrag. Det blir mye ordentlige samtaler om hva som betyr noe. Hva betyr det å være et menneske? Hva er det viktige her og nå? Du får skrapt bort mye av bagatellene som vi styrer med til daglig og som jo er en del av et daglig liv. Mot slutten blir tilstedeværelsen mer intens. Det å leve i lys av begrenset tid gir et perspektiv på livet som leves: Hva er viktig for deg? Det er et kjernespørsmål, og folk er så utrolig forskjellige, forteller Borge.

- Jeg har truffet pasienter langt over 90 år, fulle av kreft hvor jeg forsiktig har antydet at vedkommende vil kunne dø av dette. Det var det frekkeste han hadde hørt. Så upassende at jeg kunne tenke noe sånt! Nina Borge smiler. Det gjør hun ofte.

- Mens andre har en mer fatalistisk holdning til det å dø. Og andre igjen ønsker virkelig å fryse seg ned i en kryobank for en million kroner. Min million skal ikke gå til det, for å si det sånn. Tenk deg å våkne opp etter 100 år. Hvor er resten av de du kjente, de du hadde hatt lyst til å være sammen med? spør hun og rister på hodet. Telefonen hennes ringer. Melodien er Lalehs Some die Young.

- Det er et slags memento mori, kommenterer hun raskt til valg av ringetone. Onkolog og indremedisiner Nina Borge har valgt å jobbe med døende, men er lys og lett å snakke med. Godt humør er smittsomt, slår hun fast.

- Jeg skulle ønske det var mulig å ringe å si «Hei, jeg kommer ikke på jobb i dag fordi jeg er så sur. Det er veldig smittsomt, det er nok best jeg holder meg hjemme». Og så ville jeg få til svar «Det er greit. Kom tilbake når du er blitt blid». Er ikke det en genial idé? Du kan ikke ha for mange sure folk på en arbeidsplass. Det er smittsomt på lik linje med influensa, konstanterer Borge.

\section{En forkjærlighet for døden}

Selvhøytidelig eller pompøs er ikke ord som slår deg i møte med Borge, til tross for at hun i jobben nesten daglig konfronteres med tilværelsens store spørsmål. Det er ikke bare Erik Bye som har vært blant Borges profilerte pasienter. Per Fugelli er en annen.

\section{Nina Borge}

Født 1958 i USA

- Cand.med., Universitetet i Oslo 1984

- Turnustjeneste, Nordland sentralsykehus, Bodø 1985

- Distriktsturnus i Gildeskål kommune, Nordland 1986

- Det norske radiumhospital 1986-91

- Diakonhjemmet Sykehus 1991-2016

- Vinderen bo- og servicesenter 2016-d.d.

- Rådgivende lege i Fransiskushjelpen 2007-d.d.

- Godkjent spesialist i onkologi 1994

- Godkjent spesialist i indremedisin 2001

Han er hes i stemmen, har metastaser blant annet i lillehjernen, og sliter tidvis med 
trykksymptomer som gir store plager. Han traff Nina Borge via Fransiskushjelpen fordi han $\emptyset$ nsket å dø hjemme.

- Du kan si vi begge har en forkjærlighet for døden, humrer Fugelli. Tross få krefter forteller han mer enn gjerne om sitt forhold til klinikeren og mennesket Nina Borge.

- For meg så bærer hun i seg de verdiene og den kyndigheten som en god lege bør ha - det du lengter etter at en god lege skal være når du bruker så lang tid på å dø som meg.

Fugelli tar en pause før han fortsetter:- Hun kan faget sitt 100\% og er kjempekompetent på det å hjelpe folk til å dø så lite ille som mulig, sier han og kaller henne sin fastlege for den siste tiden.

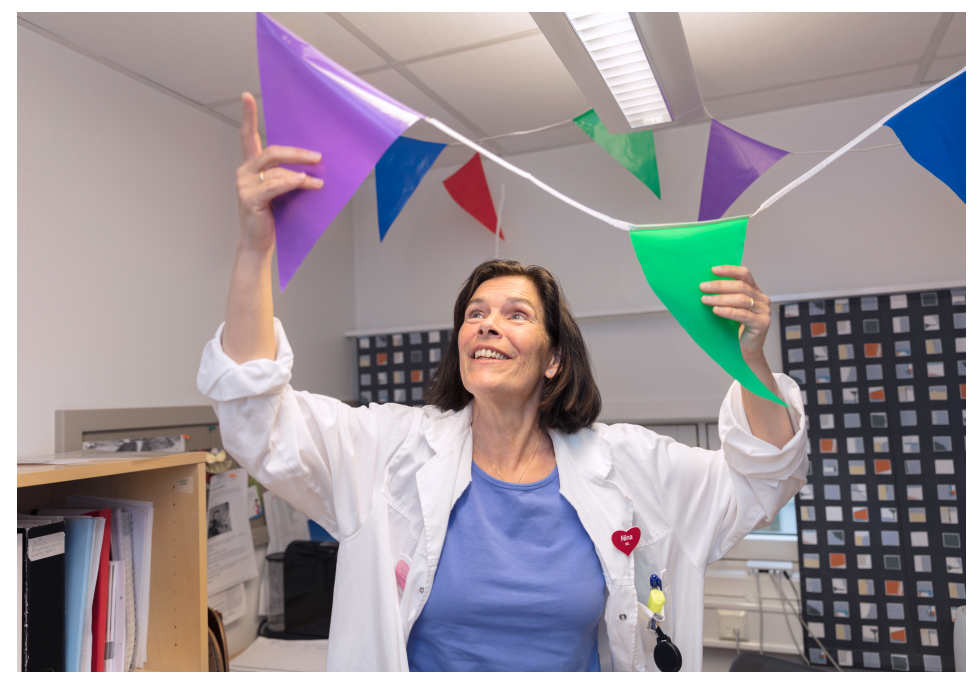

- Når man begynner å få gnagsår på knoklene... så er Nina en utrolig dyktig lege for en kropp som dør bit for bit. Jeg tenker at dette er så viktig og ganske forsømt. Hun tar faget medisin på det dypeste alvor. For det er ikke bare en kropp som dør, celler som slutter å virke som de skal og organer som svekkes, men i denne kroppen bor også det vi kaller en ånd eller en sjel. Jeg vet ikke om Nina Borge har Gud eller hva hun har av tro, men hun vet $\mathrm{i}$ hvert fall om den. Hun tar sjelen på alvor uten å bli invasiv, sier Per Fugelli underfundig.

\section{En turkamerat}

- Det var hyggelig sagt. Det er jo en gyllen balanse det der å ta sjelen på alvor uten å bli invasiv, sier Borge. Hun tar en liten pause.

- Som palliasjonslege ser jeg på meg selv som en turkamerat på den siste reisen. Man kan tenke på det som en fjelltur der veien er en vei som ingen av oss har gått før. Vi vet ikke hvor lang den er, men jeg er kjent i fjellet. Jeg kan kanskje se når det er uvær på gang og når man skal søke ly eller ta seg en pause. Jeg tenker at det å være en god turledsager på den veien kan være med på å gi en trygghet. Trygghet betyr veldig mye, og det å få kontinuitet på den reisen tror jeg er viktig. Palliasjon er et helt fantastisk fag, vet du, sier Borge og smiler.

Hun er også opptatt av å inkludere de pårørende i arbeidet. - Pårørende er den viktigste heiagjengen. Jeg heier også, men jeg er en profesjonell cheerleader. Når pasienten blir dårligere og dårligere, er det ikke bare lindring og ivaretagelse av den syke som er sentralt. Da vil også de pårørende trenge støtte for å tåle å stå i det. De er en selvfølgelig del av helheten. Jeg pleier å si til dem som vil dø hjemme at det er de pårørende som har vetoretten til å si fra når nok er nok. Da er det ikke lenger pasientens vilje som gjelder. Pårørende kan bli veldig slitne, men det er ofte likevel stor vilje hos dem til å innfri det $\emptyset$ nsket - i hvert fall hvis det er gode relasjoner.

- Du har vært lege for flere profilerte mennesker som virkelig har fått brukt sitt potensial. Hva med de som kommer til slutten og føler at de ikke har oppnådd det de ønsket? Døden vekker mange følelser.

- Det har du rett i. Det kan være veldig smertefullt å komme til et punkt der det er slutt. Det 
er tungt. Da er det enda viktigere å putte mening og innhold i de dagene som måtte være igjen. Det kan være en stor sorg at livet ikke ble som han hadde tenkt, håpet eller fikk til. Det er jo også veldig mye flaks eller uflaks i disse livene våre, sier hun og fortsetter:

- Jeg er opptatt av hva som er viktig for den enkelte. Det som er viktig for meg er gode ord og møter, relasjoner og humor. Får du til å le selv om du er kjempesyk og på vei ut av livet, så har det i seg selv masse verdi. Det er jo fantastisk å le. Humor har alltid vært viktig for meg. Man skal være litt forsiktig, men hvis du treffer, er det gyllent farvann, sier Borge og understreker: - Humoren må være tilpasset og veldig nøye titrert, for å si det sånn.

\section{En ung spirrevipp}

Nina Borge startet allerede under medisinstudiet å interessere seg for palliasjon og ble rekruttert til foreningen Retten til en verdig død. Hun var en periode sekretær og senere viseformann for foreningen.

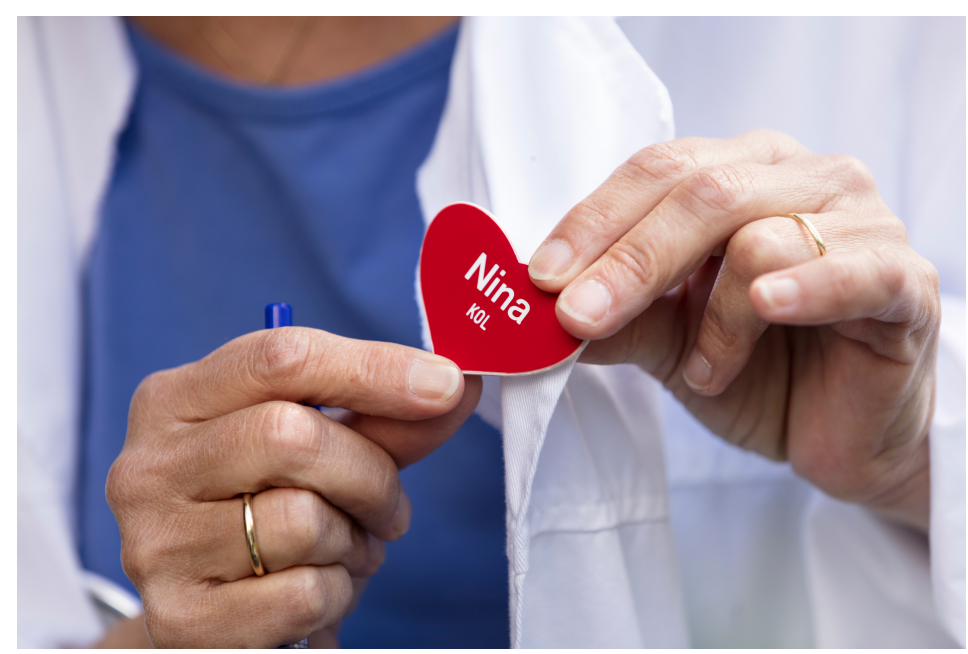

- Jeg var en ung spirrevipp og hadde egentlig ikke greie på noen ting, men det handlet blant annet om god symptomlindring til døende. Det var litt andre forhold på den tiden. Etter hvert har den foreningen pinadø gått inn for aktiv dødshjelp. Det er jeg imot. Ferdig med det, sier Borge og gjentar ordet «imot» tre ganger etter hverandre.

- Det er ikke det at jeg ikke kan forstå at noen mennesker får så vanskelige livsbetingelser at de ber om den hjelpen. Men det å sette en annen person til å ta vurderingen om et ja eller nei og deretter effektuere den, det er der problemet ligger. Det er ingen legeoppgave, mener sykehjemslegen og siterer nevrolog Morten Horn: Det er mange gode grunner for eutanasi og det er enda flere imot. Jeg har landet helt på at dette ville jeg ikke kunnet være en del av, sier overlegen. Hun setter kaffekoppen fra seg og fastslår i tilfelle vi skulle være i tvil:-Så jeg er ikke medlem i den foreningen lenger.

- Jeg har inntrykk av at vi i vår tidsalder kanskje er litt mer opptatt av kontroll. Jeg tror det er en del av dette behovet som gjør at folk også ønsker å kontrollere sin utgang. Mesteparten av livet er jo ukontrollerbart, men vi lever likevel i illusjonen om at vi har kontroll. Virkeligheten er ikke sånn. Ingen av oss har kontroll over en fødsel for eksempel. Død og fødsel er veldig likt. Vi vet det nærmer seg og man kan sette en termin alt man orker, ikke sant, til du blir blå, men de færreste kommer til termin. De aller fleste kommer litt før eller litt etter. Be you sure, understreker Borge og avslører sin amerikanske bakgrunn. Hun ble født i USA der faren jobbet som forretningsmann, og bodde i New York frem til hun var fem år.

- Da jeg kom til Bergen og begynte i barnehage, ble jeg forbløffet over at ingen snakket engelsk, husker Borge. Hun snakket kav bergensk da hun ett år senere flyttet videre til Bærum. Der har hun bodd siden. - Da la jeg bergensdialekten fort bort, forteller hun lakonisk. Hun har fremdeles dobbelt statsborgerskap og en søster som bor og jobber i USA. 


\section{En merkevare for Diakonhjemmet}

Overlegen jobbet 25 år ved Diakonhjemmet Sykehus. Her har hun blant annet vært med på å bygge opp et palliativt team, et tilbud som etter hvert ble så populært at det ikke kunne dekke etterspørselen. Nina Borge ble en merkevare for sykehuset, bemerker en kollega. Betydningen av en fast lege i livets sluttfase er det flere enn Per Fugelli som setter pris på, men sykehusøkonomi er ikke alltid på pasientenes side.

På grunn av økende arbeidsbelastning uten $\emptyset$ kte ressurser valgte hun til slutt å gå, men med tungt hjerte. I dag jobber hun på sykehjemmet Vinderen bo- og servicesenter. På vaktrommet treffer vi en avdelingsleder og forklarer at vi kommer for å gjøre et portrett på Borge. - Ja, det skjønner jeg godt, svarer damen og legger til i farten: - Hun må være det beste som har skjedd sykehjemsmedisinen.

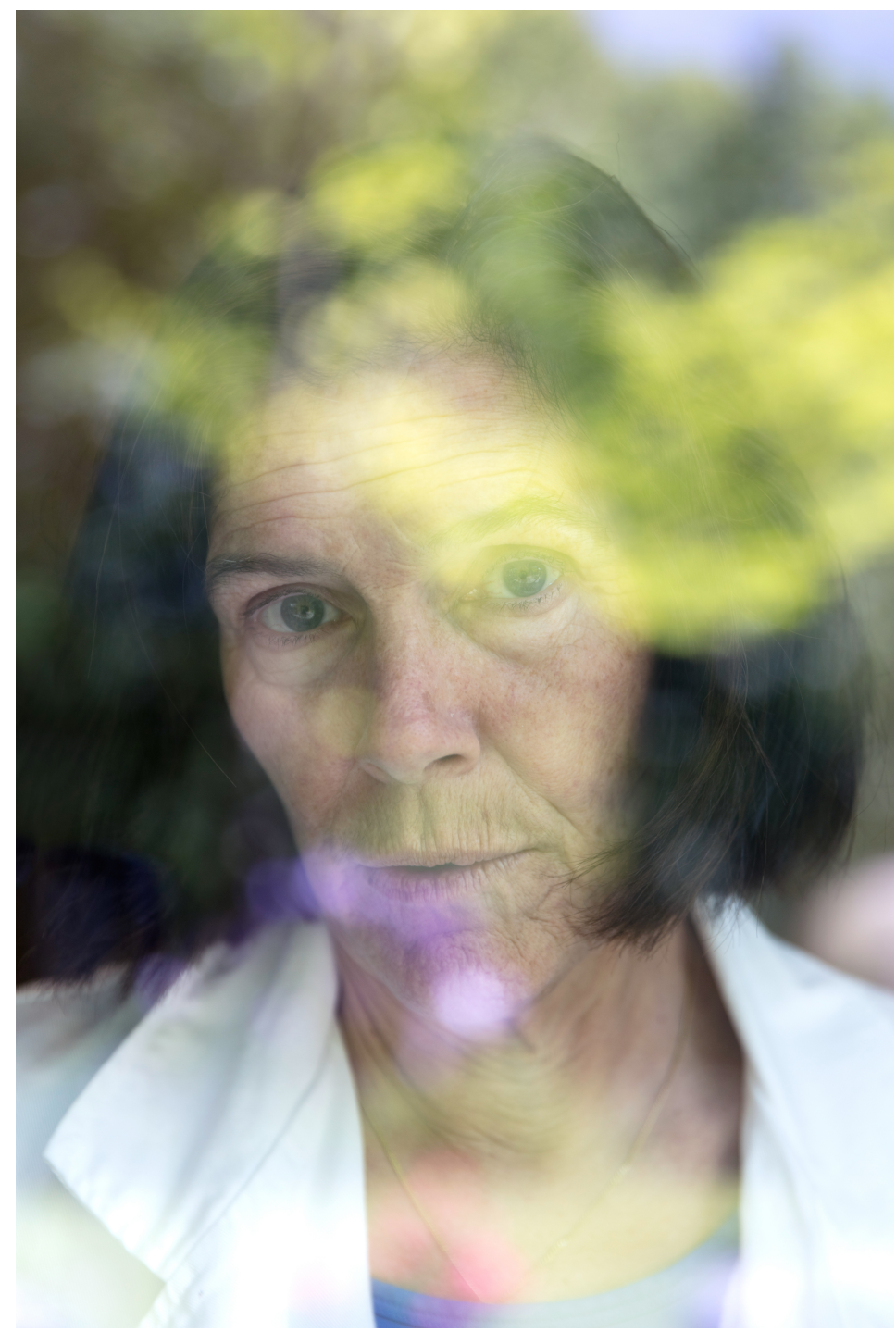

Lenger ned i gangen ligger Borges kontor. På vei inn henger en gammel tegning fra en forside på en legeroman, med påskriften «Kärlek i vitt». - Min mann, Lasse Blystad, var også lege på Diakonhjemmet, og dette bildet hang utenfor vårt felles kontor, forteller hun. - Da jeg flyttet inn på kontoret hans fikk jeg laget et skilt der det sto «Overlege Lasse Blystad med frue», forteller Borge og ler. - Men han la ned forbud mot å snakke jobb når vi kom hjem. Han var streng der, men det tror jeg var bra for meg. Jeg kunne snakket fag døgnet rundt og drevet omgivelsene til vanvidd, mener hun.

Vel inne på kontoret finner vi enda et eksempel på hennes popularitet på den nye arbeidsplassen. I taket henger fargerike vimpler i taket og vitner om festlig lag. - Jeg kom på jobb her en dag i slutten av mai da jeg fylte år, det var ikke et rundt år engang, og ble overrasket med ballonger overalt, vimpler i taket, flagg og kake. Utrolig hyggelig, sier Borge. Ikke alle ferske arbeidstagere opplever 17.mai-stemning når de fyller år etter et knapt års 
ansettelse, men Borge utbroderer ikke mer om det. Smilet blir borte et lite øyeblikk. Hun husker spesielt en pårørende som kom for å snakke med henne denne dagen. - Det var en veldig trist pårørende som satt her i gangen... og så var det ballonger overalt, all den gleden... Det var et spesielt bilde, forteller Borge og studerer vimplene i taket. - Jeg er litt usikker på om de skal bli værende som i et slags Pippi Langstrømpe-hus eller om jeg skal rydde dem ned. Hva synes du?

\section{«Be good»}

Ukentlig opplever Borge at pasienter faller fra, men alvoret hennes er ikke tungsindig.

- Det er en uforutsigbarhet knyttet både til inngangen og utgangen i livet. Du er forhåpentligvis omgitt av dine nærmeste både på vei inn og ut, og både fødsel og død kan være veldig høytidelig. Det er noe mirakuløst. Noe vi ikke skjønner bæret av. Hva er det egentlig som skjer? Er det noe som heter sjel og fri vilje, eller er det loddet fast i hjernen? Det som er så rart, er at når noen er død, så ser man det med én gang. Da er bare innpakningen igjen. Hvor i all verden blir sjelen av? undrer Borge.

- Det som er så vidunderlig med eksistensielle spørsmål er at det er ingen som forventer at jeg har svarene. Min tanke rundt dette kan være like god som din. Det handler om å tenke rundt temaene og undre seg sammen og å tåle å ikke ha svarene, sier hun.

- Er det noen spesielle innsikter denne jobben likevel har gitt deg?

Nina Borge ler igjen. - Jeg vet jo ikke meningen med livet, men jeg vet mye om mening $i$ livet. For de fleste er det familie og relasjoner. Det å være glad i noen, ha betydd noe for noen, og det å ha fått brukt sitt potensial. Per er spennende å snakke med når det gjelder dette med mening, legger hun til. På oppslagstavlen på kontoret hennes henger det en forside fra Lancet der Per Fugelli også er sitert: «Colleagues, I have no God, but I do have Saints, the eternal values of medicine: do good, be just, respect nature».

- Status og karriere blir ofte fremhevet. Jeg liker dette Fugelli-sitatet. Det er helt i Hippokrates’ ånd. Særlig er det å være snill, «be good», litt undervurdert. Det er en egenskap virkelig verdt å kultivere, sier Borge. Hun er ingen stor tilhenger av produksjonstenkningen som preger mange sykehus for tiden. - Ikke alt som teller kan telles, og ikke alt som telles teller, sa visst Einstein. Det støtter jeg fullt ut, avslutter Borge.

Per Fugelli døde 13.9.2017. Dette intervjuet ble skrevet før han døde.

Publisert: 2. oktober 2017. Tidsskr Nor Legeforen. DOI:10.4045/tidsskr.17.0622

(C) Tidsskrift for Den norske legeforening 2020. Lastet ned fra tidsskriftet.no 